\title{
Feeding ecology and movements of the Barolo shearwater Puffinus baroli baroli in the Azores, NE Atlantic
}

\author{
Verónica C. Neves ${ }^{1, *}$, Joël Bried ${ }^{1}$, Jacob González-Solís ${ }^{2}$, Jose L. Roscales ${ }^{2,3}$, \\ Malcolm R. Clarke ${ }^{4}$ \\ ${ }^{1}$ Departamento de Oceanografia e Pescas, Centro do IMAR da Universidade dos Açores, Rua Frederico Machado ${ }^{\circ} 4$, \\ 9901-862 Horta, Faial, Azores, Portugal \\ ${ }^{2}$ Institut de Recerca de la Biodiversitat (IRBio) and Departament de Biologia Animal, Universitat de Barcelona, \\ Avenida Diagonal 645, 08028 Barcelona, Spain \\ ${ }^{3}$ Departamento de Análisis Instrumental y Química Ambiental, Instituto de Química Orgánica general (IQOG-CSIC), \\ Calle Juan de la Cierva 3, 28006 Madrid, Spain \\ ${ }^{4}$ Rua do Porto 18, 9930-430 Lajes do Pico, Azores, Portugal
}

\begin{abstract}
Trophic ecology and movements are critical issues for understanding the role of marine predators in food webs and for facing the challenges of their conservation. Seabird foraging ecology has been increasingly studied, but small elusive species, such as those forming the 'little shearwater' complex, remain poorly known. We present the first study on the movements and feeding ecology of the Barolo shearwater Puffinus baroli baroli in a colony from the Azores archipelago (NE Atlantic), combining global location-sensing units, stable isotope analyses of feathers $\left(\delta^{13} \mathrm{C}\right.$ and $\left.\delta^{15} \mathrm{~N}\right)$, stomach flushings and data from maximum depth gauges. During the chick-rearing period, parents visited their nests most nights, foraged mainly south of the colony and fed at lower trophic levels than during the non-breeding period. Squid was the most diverse prey (6 families and at least 10 different taxa), but species composition varied considerably between years. Two squid families, Onychoteuthidae and Argonautidae, and the fish family Phycidae accounted for $82.3 \%$ of ingested prey by number. On average, maximum dive depths per foraging trip reached $14.8 \mathrm{~m}$ (range: 7.9 to $23.1 \mathrm{~m}$ ). After the breeding period, birds dispersed offshore in all directions and up to $2500 \mathrm{~km}$ from the breeding colony, and fed at higher trophic levels. Overall, our results indicate that the Barolo shearwater is a non-migratory shearwater feeding at the lowest trophic level among Macaronesian seabirds, showing both diurnal and nocturnal activity and feeding deeper in the water column, principally on small schooling squid and fish. These traits contrast with those of 3 other Azorean Procellariiformes (Cory's shearwater Calonectris diomedea, the Madeiran storm-petrel Oceanodroma castro and Monteiro's storm-petrel O. monteiroi), indicating ecological segregation within the Azorean seabird community.
\end{abstract}

KEY WORDS: Barolo shearwater - Puffinus baroli baroli $\cdot$ Diet $\cdot$ Foraging behaviour $\cdot$ Stable isotopes · Activity patterns · At-sea distribution · North-eastern Atlantic

\section{INTRODUCTION}

Seabirds are a major component of the marine ecosystem and generally thought to be at the top of the marine food webs (Brooke 2004b, Karpouzi et al.
2007). However, their feeding ecology and movements across marine ecosystems remain poorly known for many species. This lack of knowledge hampers our understanding of the role of seabirds in marine ecosystems, our capability to identify the 
threats to their populations and, thus, the conservation of these marine predators.

Trophic interactions have been typically studied through diet analyses from e.g. stomach flushing (Wilson 1984, Ridoux 1994, Neves et al. 2011). This method has been extensively used in subantarctic and Antarctic seabirds (e.g. Ridoux 1994, Connan et al. 2008), but species of the sub-tropical northern hemisphere, particularly the Atlantic Ocean, remain poorly studied (Croxall \& Prince 1996). Traditional studies of diet composition, however, have mainly been conducted during the breeding period, are biased towards prey with hard parts and only give information from the last meal. Nevertheless, they are very important for determining prey type and size, and especially useful when used in association with other tracers of feeding ecology which integrate the diet over longer periods, such as ratios of carbon and nitrogen stable isotopes (e.g. Rau et al. 1982, Hobson \& Welch 1992, Thompson et al. 1999, Forero et al. 2004). Despite a few exceptions however (e.g. Petry et al. 2008), our knowledge of seabird diets during the non-breeding period is very limited (Barrett et al. 2007). Stable isotope analyses have been increasingly used and are improving our understanding of the role of seabirds in marine food webs, but values are often difficult to interpret because in many cases, such as in most Procellariiformes (petrels) breeding in Macaronesian archipelagos, we still lack basic knowledge of diet composition (Roscales et al. 2011a).

Isotope ratios in consumer tissues reflect those of their prey in a predictable manner (DeNiro \& Epstein 1978, 1981, Hobson \& Clark 1992a,b), and since tissues turn over at different rates, they can integrate trophic information over different temporal periods and, if the animal migrates, over different areas as well (Hobson \& Clark 1992b, Ramos \& González-Solís 2012). In the marine environment, higher ratios of ${ }^{13} \mathrm{C}$ to ${ }^{12} \mathrm{C}\left(\delta^{13} \mathrm{C}\right)$ in seabird tissues characterize inshore and benthic habitats compared to offshore and pelagic environments (France 1995, Kelly 2000). The ratio of ${ }^{15} \mathrm{~N}$ to ${ }^{14} \mathrm{~N}\left(\delta^{15} \mathrm{~N}\right)$ has been largely used to delineate consumer trophic positions because $\delta^{15} \mathrm{~N}$ increases with trophic level due to preferential incorporation of ${ }^{15} \mathrm{~N}$ into body tissues (Minagawa \& Wada 1984, Owens 1987). Moreover, stable isotopes can also provide information about the spatial component of the trophic niche because tissues ultimately integrate the isotopic baseline levels of the area where they were formed. Feathers are especially useful for this purpose when moulting patterns are known because they reflect the isotopic forms assimilated through the diet when and where they were grown (Hobson \& Clark 1992b). This is important in seabirds, whose main feeding areas have been typically difficult to locate due to the pelagic habits of these species. However, the spatial resolution of stable isotopes is low or even null if birds just move within a regional scale. For example, movements within the Northeast Atlantic are unlikely to be isotopically detected because baseline values are essentially homogeneous (Graham et al. 2010, Roscales et al. 2011a). Alternatively, tracking devices can provide more detailed information on bird movements (Burger \& Shaffer 2008). As a consequence, the use of light-based geolocators (global location-sensing units) has increased substantially over the last few years (although very incomplete, the list presented at the British Antarctic Survey website includes 8 peer-reviewed papers up until 2005 and 47 up until 2010). Despite their relative lack of accuracy (about 200 km, Shaffer et al. 2005), geolocators are useful for identifying broad foraging areas during both the breeding and the non-breeding periods. In addition, geolocators can also provide insights into the temporal component of the trophic niche, since some of these loggers can also record daily activity patterns at sea (e.g. Passos et al. 2010).

A combination of traditional approaches with more recent methods can provide a broader picture of seabird foraging ecology, since each method complements the limitations of the others (Hobson et al. 1994, Hobson 1999, Fry 2006, González-Solís et al. 2007a). In the present study, we used geolocators, stable isotope analyses of feathers $\left(\delta^{13} \mathrm{C}\right.$ and $\left.\delta^{15} \mathrm{~N}\right)$, stomach flushings and maximum depth gauges to study the movements and feeding ecology of one of the species forming the 'little shearwater' complex, the Barolo shearwater Puffinus baroli. The Barolo shearwater is endemic to the NE Atlantic oceanic islands, breeding only in the Azores, Madeira, Salvages, Canary and Cape Verde archipelagos, with the $P$. baroli baroli subspecies breeding in the former 4 archipelagos and the $P . b$. boydi subspecies breeding on the Cape Verde islands (Brooke 2004a). Due to its restricted range and its limited numbers $(<7000$ breeding pairs), the Barolo shearwater is considered 'Rare' in the Palearctic (BirdLife International 2004). The movements, foraging areas and diet of the smallest and most secretive shearwater of the subtropical Atlantic remain largely unknown. Therefore, it is essential to evaluate the factors that may alter the current and future dynamics of its populations as well as help identify important conservation areas at sea. 
The main aims of this study were: (1) to assess the diet composition and main prey of the Barolo shearwater; (2) to characterize its foraging behaviour; and (3) to identify its main foraging areas during the breeding and non-breeding periods.

\section{MATERIALS AND METHODS}

The present study was conducted in the Azores, where the species reaches the northern limit of its distribution. At this locality, the population of Barolo shearwaters is estimated to consist of between 840 and 1530 breeding pairs (Monteiro et al. 1999), making it the second most abundant procellariiform in the region after Cory's shearwater Calonectris diomedea. Fieldwork was conducted on Vila islet

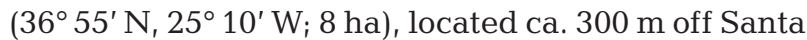
Maria island, Azores archipelago, which holds about 50 breeding pairs of Barolo shearwaters (Monteiro et al. 1999). Egg laying occurs from late January, chicks hatch from mid-March and fledge from mid- to late May (Monteiro et al. 1996). Adults stop visiting the colonies between June and September. The primary remiges are moulted in April and May when most birds are renewing primaries 1 to 4, and the moult of the secondary remiges occurs towards the end of the non-breeding period (Monteiro et al. 1996).

\section{Diet}

Stomach contents were collected under license between 26 and 29 March 1998 and between 20 and 25 April 2000, to coincide with the chick-rearing stage. Barolo shearwaters can be very asynchronous breeders (Monteiro et al. 1996, J. Bried unpubl. data) and when we visited Vila islet in March 1999, very few chicks had hatched, preventing us from repeating the sampling. Therefore in 2000, we decided to visit the islet some weeks later than in 1998 to ensure the success of sampling. Diet samples were obtained from adult birds using the water-offloading technique (Wilson 1984); each individual was sampled only once. For the wateroffloading procedure, we used a syringe and a plastic suction catheter with an external diameter of $2.3 \mathrm{~mm}$. Birds were ringed using individually numbered metal rings and released immediately after being sampled. In the field, food samples were drained and preserved in $70 \%$ ethanol. Samples were examined and sorted under a binocular microscope. Otoliths were kept dry and all the other remains from fish, cephalopods and crustaceans were stored in $70 \%$ ethanol. Fish were identified to the lowest possible taxon from their otoliths using available keys (Nolf 1985, Härkönnen 1986, Smale et al. 1996) and reference collections. Otoliths were paired to estimate the number of fish prey in each sample. Cephalopods were identified from their beaks and, when they were not too digested, from flesh, shape, color and other physical features. The body mass (M) and mantle length (ML) of cephalopods were estimated from measurements of rostral length, or hood length for octopods, of wellpreserved lower beaks, using the equations published by Clarke (1986). In the cases of Argonauta argo and Tremoctopus violaceus, the equations of Smale et al. (1993) were used. Given that the length of the arms of cephalopods in relation to ML varies considerably among species, we also provided estimates of standard length (SL), which is the length of a squid excluding the tentacles. SL may give a better idea of the size of the prey from the predator's point of view. Estimates of SL are based on ML-SL relationships from drawings published by Nesis (1987). Diet composition is described by both frequency of occurrence (FO, percentage of samples containing each type of prey) and numerical frequency ( $\mathrm{NF}$, individual numbers of each prey type). Differences in the NF of prey types between years were assessed using chi-square tests. Stomach contents consisted of a dense grey paste and no prey items were found whole, precluding weighing individual items. Crustaceans were too digested, preventing specific identification and fish prey could only be identified through otoliths since the other hard structures were very small and eroded. Squid beaks are known to be more resistant to digestion than otoliths, and therefore tend to accumulate in bird stomachs for a longer period, leading to an overestimation of the squid contribution to the overall diet (Furness et al. 1984, Jackson \& Ryan 1986, Neves et al. 2006). To avoid this bias, Neves et al. (2006) suggested using only the beaks that are still attached to their buccal masses. In our case, however, this would result in an overestimation of fish prey from otoliths by drastically reducing the diversity and abundance of squid prey, since only 22 out of 248 intact lower beaks were found on their buccal masses. Therefore, we used all the lower beaks except those that were eroded or partially broken. Upper beaks were not used for species identification, but we used them to calculate the average number of specimens per sample whenever their number exceeded the number of lower beaks. 


\section{Stable isotopes analyses}

The innermost primary (P1) and the eighth secondary (S8) remiges were taken under license from 20 adult birds captured in the colony at night: 10 birds were sampled between 17 and 21 April 2004 and another 10, including the birds whose geolocators were recovered (see below), between 16 and 22 April 2008. Birds were ringed and released immediately after sampling and feathers were stored in polyethylene bags prior to isotope analyses. We examined the ${ }^{13} \mathrm{C} /{ }^{12} \mathrm{C}\left(\delta^{13} \mathrm{C}\right)$ and ${ }^{15} \mathrm{~N} /{ }^{14} \mathrm{~N}\left(\delta^{15} \mathrm{~N}\right)$ ratios in the P1, generally grown in May, corresponding to the end of the breeding season (Monteiro et al. 1996), and in the S8 remige, which is presumed to be grown in August or September, corresponding to the end of both the non-breeding and moulting periods (Monteiro et al. 1996). Feathers were cleaned in a solution of $\mathrm{NaOH}(0.25 \mathrm{M})$, oven dried at $40^{\circ} \mathrm{C}$, and cut finely with stainless steel scissors for sample homogenization. Weighed sub-samples $(0.36 \mathrm{mg})$ of feathers were placed into tin buckets and crimped for combustion. Isotopic analyses were carried out by EAIRMS (elemental analysis-isotope ratio mass spectrometry) by means of a ThermoFinnigan Flash 1112 elemental analyzer coupled to a Delta isotope ratio mass spectrometer via a CONFLO III interface (Serveis Científico-Tècnics, University of Barcelona). Stable isotope ratios were expressed in conventional notation as parts per thousand (\%o), according to the following equation: $\delta X=\left[\left(R_{\text {sample }} / R_{\text {standard }}\right)-1\right]$ where $X$ is ${ }^{15} \mathrm{~N}$ or ${ }^{13} \mathrm{C}$ and $R$ is the corresponding ratio ${ }^{15} \mathrm{~N} /{ }^{14} \mathrm{~N}$ and ${ }^{13} \mathrm{C} /{ }^{12} \mathrm{C}$. The standards for ${ }^{15} \mathrm{~N}$ and ${ }^{13} \mathrm{C}$ are atmospheric nitrogen (AIR) and Vienna Peedee Belemnite (VPDB), respectively. Reference materials for stable isotope analysis were provided by the International Atomic Energy Agency (IAEA). In the case of $\delta^{15} \mathrm{~N}$, the standards (certified reference value $\pm \mathrm{SD}, \%_{\text {air }} 2$ for $\left.\delta^{15} \mathrm{~N}\right)$ used were IAEA-N-1 $(0.4 \pm$ $0.2 \%)$, IAEA-NO-3 $(4.7 \pm 0.2 \%)$ and IAEA-N-2 $(20.3$ $\pm 0.2 \%$ ) and the experimentally obtained values were $0.5 \pm 0.2,4.6 \pm 0.1$ and $20.3 \pm 0.1 \%$, respectively. USGS 40 (certified reference value $\pm \mathrm{SD}$, $\%$ ovPDB for $\delta^{13} \mathrm{C},-26.389 \pm 0.042 \%$ ), IAEA-CH-7 $(-32.151 \pm 0.050 \%)$ and IAEA-CH-6 $(-10.499 \pm$ $0.033 \%$ ) were the reference materials for $\delta^{13} \mathrm{C}$ measurement. The values obtained in the laboratory for these standards were $-32.17 \pm 0.05,-26.37 \pm 0.03$ and $-10.46 \pm 0.03 \%$, respectively. Standards span the range of sample isotope ratios. Accuracy was $\leq 0.1 \%$ or $\delta^{13} \mathrm{C}$ measurements and $\leq 0.2 \%$ for $\delta^{15} \mathrm{~N}$. Precision (RSD, SD $\times 100 /$ mean) for the reference materials with isotopic values within the range obtained in feather samples was $0.28 \%$ and $1.3 \%$ for $\delta^{13} \mathrm{C}$ and $\delta^{15} \mathrm{~N}$, respectively. Results are shown as means $\pm \mathrm{SD}$. In order to cover more years, stable isotope data were analyzed after combining our data with those of Roscales et al. (2011a), which were obtained from 10 other adult individuals sampled on 27 and 28 August 2003.

In order to simultaneously evaluate the effect of feather type (intra-subject factor with repeated measures) and sampling year (inter-subjects factor) on stable isotope values, we used separated multivariate analyses of variance (MANOVAs) for $\delta^{13} \mathrm{C}$ and $\delta^{15} \mathrm{~N}$.

\section{Diving abilities}

From 18 to 21 April 2004, the 2 adults of 3 chickrearing pairs were captured in their burrows at night while feeding their single chick, ringed for identification, equipped with a maximum depth gauge (MDG) fitted on the back feathers using waterproof adhesive tape, and released into their burrows. During subsequent nights, burrows were monitored to check for the return of the adults. When present, adults were captured again, the gauges were recovered and the birds were eventually equipped with another gauge before being released into their burrows. MDGs consist of plastic tubes (10 to $12 \mathrm{~cm}$ length, $0.8 \mathrm{~mm}$ internal diameter, Tygon $($ ) lined with icing sugar and sealed at one extremity (Burger \& Wilson 1988). They are commonly used to study seabird diving performances (review in Bocher et al. 2000), and their low mass ( 0.8 to $1 \mathrm{~g}$, data from this study) makes them especially suitable for small-sized species. MDGs only give the maximum depth reached. The latter is calculated following Burger \& Wilson (1988). To compare maximum depths reached between individuals, we used a Kruskal-Wallis test for small samples.

\section{At-sea distribution and activity patterns}

Ten global location-sensing loggers (MK14 geolocators, British Antarctic Survey) were deployed on breeding Barolo shearwaters from 11 to 15 April 2007, and 4 of these geolocators were recovered between 16 and 21 April 2008 (at this time, feathers were taken from the birds that carried geolocators for isotope analyses, 'Stable isotopes analyses'). Of the 10 equipped birds, 7 had a chick, 2 were still incubating and 1 was of unknown breeding status since the nesting cavity was too deep to confirm the presence of either an egg or a chick. All the nests were 
checked on 14 May 2007, about 1 mo after geolocator deployment: 1 chick had fledged and the other 6 were still in their nests. The 2 nests where the birds were still incubating when they were equipped had failed and the nest of unknown breeding status had no chick, so either the breeding attempt performed by the owner of this nest failed or the bird did not attempt to breed. Loggers were attached with a cable tie to a darvic ring and represented less than $1.5 \%$ of bird body mass (on average, equipped birds weighed $174.1 \pm 13.6 \mathrm{~g}$ and loggers about $2.5 \mathrm{~g}$, including darvic ring and cable tie). Only 1 member of each pair was equipped. Sex was determined by molecular methods (Fridolfsson \& Ellegren 1999) using a $50 \mu \mathrm{l}$ blood sample collected from the tarsal vein.

Light values obtained from geolocators are measured every minute and the logger stores the maximum reading (truncated at a value of 64) at the end of every $10 \mathrm{~min}$. Light readings range from 0 (complete darkness) to 64 (full light) and sunrise and sunset thresholds were set at 20. For each bird, latitude and longitude were estimated twice a day from day and night length and the time of local midday and midnight relative to Greenwich mean time (GMT) (Phillips et al. 2004). During processing, we excluded locations derived from curves with apparent interruptions around sunset and sunrise, or that showed a flight speed index greater than $30 \mathrm{~km} \mathrm{~h}^{-1}$, as calculated by the root of the square speed average of the segments formed with the 2 preceding and the 2 following positions (González-Solís et al. 2007b). Locations around the 21 March and 21 September equinoxes were also excluded due to their inaccuracy.

Four periods were considered for the analyses (see Table 7): (1) second-half of chick-rearing, i.e. the time between logger deployment and the last day of presence at the colony, identified from location and activity data; (2) non-breeding (from the last day of colony attendance until the subsequent first day spent in the burrow during daylight); (3) prebreeding (from the date of the first day spent in the burrow during daytime until the start of incubation as seen from activity data) and (4) incubation and early chick-rearing (from the start of incubation as seen from activity data -2 or more days spent in the burrow - until logger recovery, after excluding the data around the 21 March equinox). Bird locations at sea were examined using ArcView GIS 3.2 (ESRI). The Animal Movement extension in ArcView was used to generate kernel density maps in an equalarea cylindrical projection using the least-square cross validation method, thus identifying key areas for the 4 periods. Following previous authors (e.g.
Catry et al. 2009, Paiva et al. 2010b), we identified 2 main kernel contours, namely 'core areas of activity' (50\% kernel) and 'home range' (95\% kernel), as the main descriptors of the foraging distribution of Barolo shearwater; the maps also include the areas for the $75 \%$ kernel. The core areas of activity and home ranges were mapped analyzing all birds together (see Fig. 3). To show the intra-individual variations and overlap in the core areas of activity $(50 \%$ kernel), we also present individual results for each marked bird (see Fig. 4). The loggers also had saltwater immersion sensors recording contact with saltwater every $3 \mathrm{~s}$. Immersion values corresponded to the number of contacts with saltwater for every 10 min period, ranging from 0 (no contact with saltwater) to a maximum of 200 (10 min of continuous immersion in saltwater). The activity patterns of Barolo shearwaters were derived from immersion data and matched with the light data to calculate the proportion of time and the total time spent on the water and in flight during darkness and daylight each day during the non-breeding period. During the pre-breeding, incubation and chick-rearing periods, activity patterns were only calculated during daylight because it is difficult to distinguish between flight and visits to the colony during darkness. Tracking data from the period prior to migration have been published by Roscales et al. (2011a).

We used Friedman tests to investigate whether core area and home range size varied according to the different periods of the yearly cycle (chickrearing, pre-breeding, non-breeding; incubation was not included because we only have data for 3 individuals). We also used Friedman tests to determine whether bathymetry, chlorophyll a (chl a) concentration and sea surface temperature (SST) within the core areas of each tracked individual varied according to the different periods of the yearly cycle (again we could not use incubation).

\section{Environmental data}

Remotely sensed SST $\left({ }^{\circ} \mathrm{C}\right)$ and near-surface primary productivity indicated by chl a concentration (mg $\mathrm{m}^{-3}$ ) were derived from standard mapped images collected by the Moderate Resolution Imaging Spectroradiometer (MODIS) instrument aboard NASA's Aqua satellite and obtained from the Ocean Color Discipline Processing System (Campbell et al. 1995). Monthly averages used a $9 \mathrm{~km}^{2}$ spatial resolution for SST and a $4.6 \mathrm{~km}^{2}$ resolution for $\mathrm{chl}$ a. The datasets were handled using a Geographic Information Sys- 
tem (GIS; ESRI Arc 9.3), with the aid of the Marine Geospatial Ecology Tools extension, developed by the Marine Geospatial Ecology Laboratory of Duke University (Roberts et al. 2010). Bathymetry was determined using global 1 min grids in ASCII XYZ-format (http://topex.ucsd.edu). Using ArcView GIS 3.2, we calculated average values of chl $a$, SST and underlying bathymetry for the $50 \%$ and $95 \%$ kernels for each of the periods analyzed, that is, late chickrearing in 2007, non-breeding period, pre-breeding and incubation, and early chick-rearing in 2008.

\section{RESULTS}

\section{Diet}

A total of 92 samples were collected (44 in 1998, 48 in 2000). Nine other birds (8 in 1998, 1 in 2000) had empty stomachs, and they were not included in analyses. The frequency of occurrence of the different prey types did not differ between years $\left(\chi^{2}{ }_{4}=7.970, \mathrm{p}=\right.$ 0.093). Cephalopods were the most common prey and were present in over $90 \%$ of samples (Table 1).

Otoliths showed signs of erosion but most of them could be identified from the shape and diagnostic sulcus of the Phycis genus (Table 2, Fig. 1). In 1998, 173 otoliths were found in 14 samples, 8 were too eroded to be identified and the remaining 165 otoliths were all from Phycis sp. Overall, a total of 84 specimens of Phycis sp. were found in 9 samples that contained on average 9.3 individuals ( $\min .=1$ and $\max .=27$ ). The small size of the otoliths (max. $2 \mathrm{~mm}$ ) indicates that they were from very small fish-perhaps larval stages. $P$. blennoides with a length of $60 \mathrm{~mm}$ have otoliths of $4.05 \mathrm{~mm}$ (AFORO database, www.cmima. csic.es/aforo/; Lombarte et al. 2006), so our specimens were well below that value. This is corroborated by the fact that some Barolo shearwaters had otoliths from up to 27 individual Phycis sp. in their stomach.

Ten different kinds of lower beaks were recognized and 8 could be identified to the genus. Table 3 shows the numerical frequency of squid estimated through the lower beaks present in the stomach contents, as well as their vertical distribution. The beaks originated from 6 families and at least 10 different taxa. The 18 specimens still attached to their buccal masses were present in 9 samples from 1998 (all Onychia sp.) and 9 samples from 2000 (1 Tremoctopus violaceus, 1 Onychoteuthis sp. and 7 Argonauta argo). Additionally, 1 sample contained flesh remains and an almost complete pen of Onychia sp. or Onychoteuthis sp. measuring $40 \mathrm{~mm}$.
Argonauta argo was not detected in 1998, but 20 samples from 2000 contained beaks of this species. The 20 samples containing $A$. argo had an average of 5.7 specimens ( $\mathrm{SD}=9.3$; range: 1 to 39 )

In 1998, fish (inferred from otoliths) comprised $61.2 \%$ and cephalopods (inferred from lower beaks) $38.8 \%$ of prey by numbers, but in 2000 , fish represented only $10 \%$ and cephalopods $90 \%$ of prey $\left(\chi^{2}{ }_{1}=\right.$ 65.533, $\mathrm{p}<0.0001)$.

Table 1. Puffinus baroli baroli. Diet. Squid comprised the majority of Barolo shearwater diet (by frequency of occurrence, \%) in the Azores in 1998 and 2000. Numbers of individuals found are in brackets

\begin{tabular}{|lccc|}
\hline Taxon & 1998 & 2000 & Total \\
\hline Crustaceans & $13.6(6)$ & $14.6(7)$ & $14.1(13)$ \\
Cephalopods & $93.2(41)$ & $93.8(45)$ & $93.5(86)$ \\
Beaks & $84.1(37)$ & $93.8(45)$ & $89.1(82)$ \\
Fish & $59.1(26)$ & $52.1(25)$ & $55.4(51)$ \\
Otoliths & $31.8(14)$ & $6.3(3)$ & $18.5(17)$ \\
Number of samples & 44 & 48 & 92 \\
\hline
\end{tabular}

Table 2. Phycis sp. was the only fish prey identified in the diet of Barolo shearwater and the main fish present in their diet in 1998 (by numerical frequency, \%). Numbers of individuals found are in brackets

\begin{tabular}{|c|c|c|c|}
\hline Family/Species & 1998 & 2000 & Total \\
\hline Phycidae./Phycis sp. & $93.3(84)^{\mathrm{a}}$ & $40.0(4)^{\mathrm{b}}$ & 88.0 \\
\hline Unidentified & $6.7(6)$ & $60.0(6)$ & 12.0 \\
\hline Number of prey items & 90 & 10 & 100 \\
\hline \multicolumn{4}{|c|}{$\begin{array}{l}{ }^{\mathrm{a}} \text { Phycis sp. otoliths were present in } 10 \text { samples: } \\
\text { average } 9.3 \text { individuals (min. }=1 \text { and max. }=27 \text { ) } \\
\text { b Phycis sp. otoliths were present in only } 1 \text { sample }\end{array}$} \\
\hline
\end{tabular}

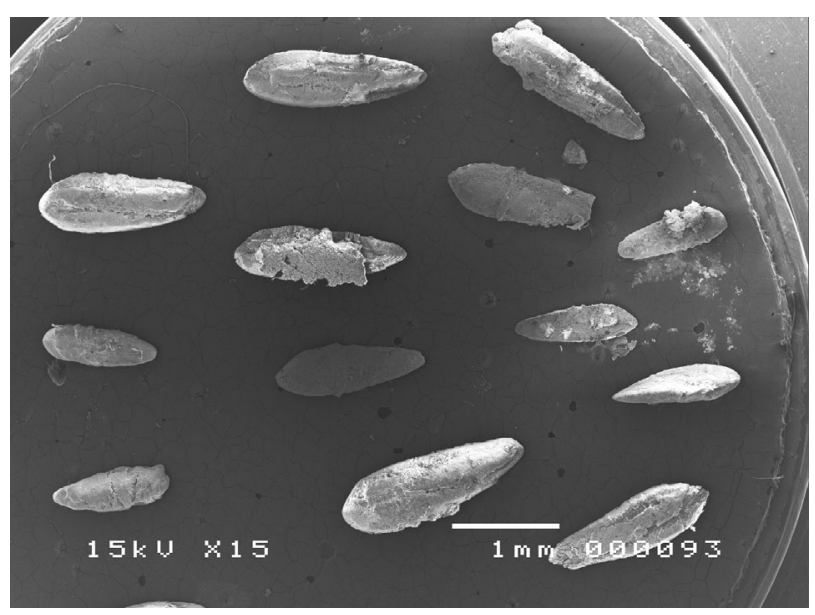

Fig. 1. Phycis sp. Scanning electron microscope image of otoliths obtained from Barolo shearwater food samples 
Table 3. Cephalopod diversity was higher than that of fish in the diet of Barolo shearwater. Birds consumed mainly Onychoteuthidae in 1998 and Argonautidae in 2000 (by numerical frequency, \%), as identified by lower beaks. Numbers of individuals are in brackets

\begin{tabular}{|lcccc|}
\hline Family & 1998 & 2000 & Total & $\begin{array}{c}\text { Vertical } \\
\text { distribution }\end{array}$ \\
\hline Genus/species & & & & \\
Decapods & & & $39.9(59)$ & \\
Ommastrephidae & & & $6.8(10)$ & \\
$\quad$ Todarodes sagittatus & - & $6.6(6)$ & $4.1(6)$ & Mesopelagic \\
Unidentified & $7.0(4)$ & - & $2.7(4)$ & \\
Onychoteuthidae & & & $30.4(45)$ & \\
$\quad$ Onychia sp. & $61.4(35)$ & $6.5(10)$ & & Epipelagic \\
Onychoteuthis sp. & & $1.1(1)$ & $0.7(1)$ & Epipelagic \\
Cranchiidae & - & $1.1(1)$ & $1.4(2)$ & Mesopelagic \\
$\quad$ Liocranchia reinhardti & $1.8(1)$ & & $0.7(1)$ & Mesopelagic \\
Taonius pavo & - & $1.1(1)$ & & \\
Histioteuthidae & & - & $60.1(89)$ & \\
$\quad$ Histioteuthis A & & & $10.8(16)$ & \\
Octopods & - & $1.8(1)$ & $1.4(2)$ & Epipelagic \\
Unidentified & $1.1(1)$ & & & \\
Tremoctopodidae & & $78.0(71)$ & $48.0(71)$ & Epipelagic \\
$\quad$ Tremoctopus violaceus & & & 148 & \\
Argonautidae & 57 & 91 & & \\
$\quad$ Argonauta argo & & & & \\
Number of prey items & & & & \\
\hline
\end{tabular}

Estimates of the mean ML of the cephalopod species (Table 4) ranged from 9.2 to $129.0 \mathrm{~mm}$ and estimated mean $M$ ranged from 1.0 to $9.1 \mathrm{~g}$. The size of the Onychia/Onychoteuthis pen found in 1 of the samples $(40 \mathrm{~mm})$ fell well within the range of $\mathrm{ML}$ estimated from lower rostral length measurements (Table 4).

\section{Analysis of stable isotopes}

$\delta^{15} \mathrm{~N}$ values varied between 4.9 and $14.1 \%$ and between 10.1 and $16.0 \%$ in P1 and S8, respectively (Table 5). In the case of $\delta^{13} \mathrm{C}$, isotope ratios ranged from -19.1 to $-16.9 \%$ in $\mathrm{P} 1$ and from -18.4 to $-7.2 \%$ in S8 (Table 5). Secondary remiges showed significantly higher $\delta^{13} \mathrm{C}$ and $\delta^{15} \mathrm{~N}$ values than primary remiges (Wilks' $\lambda, F_{1,30}=34.96$ and 25.39, respectively; both $\mathrm{p}<0.001$ ) (Fig. 2). Sampling year also had a significant influence on seabird $\delta^{13} \mathrm{C}$ and $\delta^{15} \mathrm{~N}$ values $\left(F_{2,30}=10.93\right.$ and 7.70 , respectively; both $\mathrm{p}<0.05)$. In the case of nitrogen, this was due to greater $\delta^{15} \mathrm{~N}$ values in the samples from 2008 compared to those from 2003 (post-hoc Bonferroni pairwise comparison, $\mathrm{p}<0.05)$. Inter-annual differences in carbon stable isotopes were significant due to the lower $\delta^{13} \mathrm{C}$ values obtained in 2008 compared to the rest of the sampling years (post-hoc Bonferroni pairwise comparisons, all $\mathrm{p}<0.05)$. The MANOVA also indi-

Table 4. Lower rostral lengths (LRL) and estimated mantle length (ML), standard length (SL) and body mass (M) of the squid consumed by Barolo shearwaters in the Azores. Values given are means $\pm \mathrm{SD}$, with ranges in brackets

\begin{tabular}{|c|c|c|c|c|c|}
\hline Species & $\mathrm{N}$ & Measured LRL $(\mathrm{mm})^{\mathrm{a}}$ & Estimated ML (mm) & Estimated SL (mm) & Estimated M (g) \\
\hline Todarodes sagittatus & 6 & $1.3 \pm 0.2(1.0-1.5)$ & $40.4 \pm 8.6(30.1-50.7)$ & $70.3 \pm 14.9(52.3-88.3)$ & $4.4 \pm 1.9(2.2-6.9)$ \\
\hline $\begin{array}{l}\text { Onychia sp./ } \\
\text { Onychoteuthis sp. }\end{array}$ & 40 & $1.0 \pm 0.3(0.46-1.5)$ & $36.1 \pm 13.8(4.0-62.6)$ & $51.6 \pm 23.4(6.1-94.0)$ & $2.8 \pm 1.9(0.2-8.0)$ \\
\hline Liocranchia reinhardti & 1 & 1.4 & 86.0 & 120.4 & 9.1 \\
\hline Taonius pavo & 2 & $2.3-4.2$ & $129.0-245.7$ & $150.3-286.2$ & $5.0-9.2$ \\
\hline Histioteuthis A & 1 & 0.2 & - & - & - \\
\hline Tremoctopus violaceus & 2 & $0.9-1.3$ & $19.6-28.3$ & $75.3-108.7$ & $6.5-8.5$ \\
\hline Argonauta argo & 71 & $0.8 \pm 0.6(0.2-4.1)$ & $9.2 \pm 7.5(2.0-49.2)$ & $20.2 \pm 16.5(4.3-108.2)$ & $1.0 \pm 3.8(0.003-30.5)$ \\
\hline
\end{tabular}

Table 5. Puffinus baroli baroli. Stable nitrogen isotope values of Barolo shearwater on Vila islet (Azores) are higher at the end of the non-breeding period ( $88=$ eighth secondary) than at the end of the breeding period $(\mathrm{P} 1=$ first primary). Values are means \pm SD \%. Sample sizes in brackets

\begin{tabular}{|lcccccccc|}
\hline Year & $\delta^{13} \mathrm{C}(\mathrm{P} 1)$ & Range & $\delta^{15} \mathrm{~N}(\mathrm{P} 1)$ & Range & $\delta^{13} \mathrm{C}(\mathrm{S} 8)$ & Range & $\delta^{15} \mathrm{~N}(\mathrm{~S} 8)$ & Range \\
\hline $2003(10)$ & $-18.3 \pm 0.1$ & -18.7 to -16.9 & $9.5 \pm 0.7$ & 4.9 to 11.5 & $-17.0 \pm 0.2$ & -18.1 to -15.9 & $11.8 \pm 0.4$ & 10.1 to 13.7 \\
$2004(10)$ & $-17.7 \pm 0.2$ & -19.1 to -17.0 & $10.3 \pm 0.5$ & 6.3 to 11.7 & $-16.1 \pm 0.2$ & -17.5 to -16.2 & $12.7 \pm 0.2$ & 11.9 to 14.1 \\
$2008(10)$ & $-18.3 \pm 0.1$ & -18.8 to -17.9 & $11.7 \pm 0.6$ & 8.9 to 14.1 & $-17.9 \pm 0.1$ & -18.4 to -7.2 & $13.5 \pm 0.5$ & 10.5 to 16.0 \\
\hline
\end{tabular}


cated that the interaction between feathers and years was not significant, which means that the differences in isotopic values between P1 and S8 were uniform across years for both $\delta^{13} \mathrm{C}$ and $\delta^{15} \mathrm{~N}$ (Fig. 2, Wilks' $\lambda$, $F_{1,30}=2.84$ and 0.20 , respectively; both $\mathrm{p}>0.05$ ).

\section{Maximum diving depths}

Out of the 6 birds that were equipped with MDGs, 2 were equipped once, 3 other birds were equipped twice, and the sixth bird was equipped 3 times. Ten gauges were recovered and all indicated that the

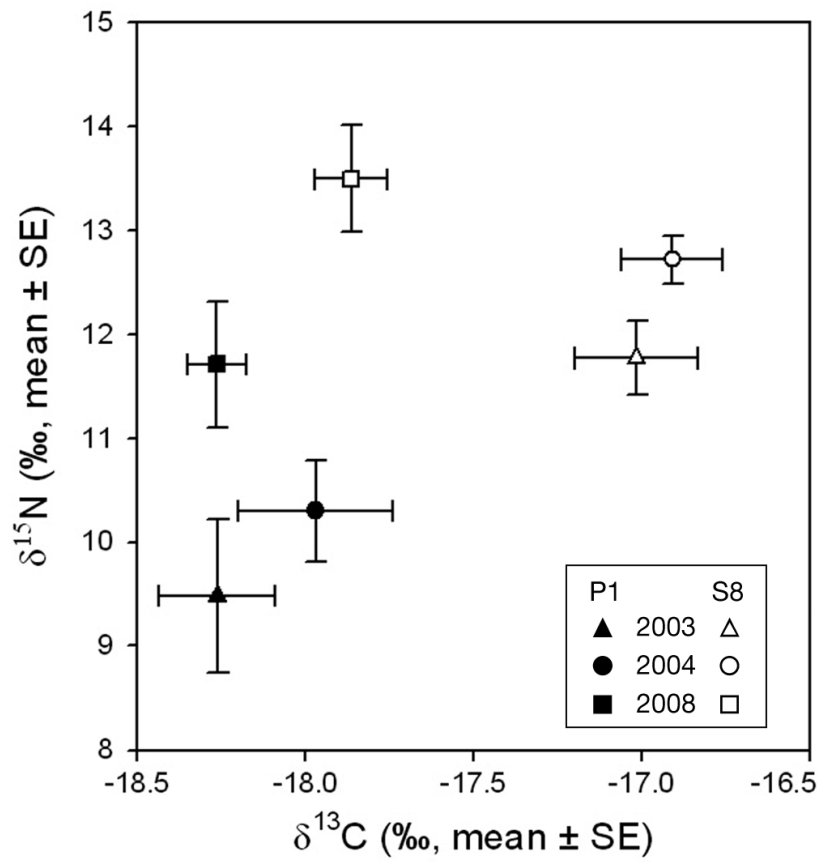

Fig. 2. Puffinus baroli baroli. Carbon and nitrogen stable isotope values (mean $\pm \mathrm{SD}$ ) in primary (P1) and secondary (S8) remiges of Barolo shearwaters in 2003, 2004 and 2008 birds had dived. However, 1 tube was not readable, that is, the boundary between dissolved and undissolved sugar was not clear-cut. Since all the birds returned, the missing gauge was lost at sea. Recorded maximum depths averaged $14.8 \mathrm{~m}$ (range: 7.9 to $23.1, \mathrm{n}=9$ gauges, Table 6), and did not differ significantly among individuals (Kruskal-Wallis test for small samples, $H_{2}=1.36, p>0.1$; only the individuals from which at least 2 gauges were recovered were considered). None of the birds equipped with MDGs were missed at night, so all gauges were recovered after a single foraging trip.

\section{At-sea distribution and activity patterns}

Only 4 of the 10 geolocators were recovered, 3 from males and 1 from a bird of undetermined sex (DNA extraction did not work for this bird); Table 7 provides details of geolocator deployment and of the breeding phenology of each individual inferred from

Table 6. Puffinus baroli baroli. Barolo shearwaters from Vila islet reach a maximum diving depth of $23.1 \mathrm{~m}$, but feed mainly in the upper $15 \mathrm{~m}$ of the water column. Each gauge was deployed during a single foraging trip

\begin{tabular}{|lcc|}
\hline Individual & $\begin{array}{c}\text { Mean maximum } \\
\text { depth (range) }\end{array}$ & $\begin{array}{c}\text { Number of } \\
\text { recovered gauges }\end{array}$ \\
\hline 1 & $19.0(14.9-23.1)$ & 2 \\
2 & 14.5 & $1^{\mathrm{a}}$ \\
3 & Gauge not readable & 1 \\
4 & $12.7(7.9-15.7)$ & 3 \\
5 & $14.7(14.0-15.5)$ & 2 \\
6 & 12.9 & 1 \\
aThis bird was equipped again and returned the \\
subsequent night but the second gauge was lost at sea
\end{tabular}

Table 7. Puffinus baroli baroli. Details of logger deployment and breeding phenology of the tracked birds. Dates are given as dd-mm-yr

\begin{tabular}{|c|c|c|c|c|c|c|c|c|}
\hline Geo (sex) & Deployed & Recovered & $\begin{array}{l}\text { End of } \\
\text { chick- } \\
\text { rearing }^{\mathrm{a}}\end{array}$ & $\begin{array}{l}\text { Start of pre- } \\
\text { breeding }^{b}\end{array}$ & $\begin{array}{c}\text { Start of } \\
\text { incubation }\end{array}$ & $\begin{array}{l}\text { Breeding } \\
\text { output } \\
2007\end{array}$ & $\begin{array}{l}\text { Breeding } \\
\text { output } \\
2008\end{array}$ & $\begin{array}{l}\text { Time away } \\
\text { from } \\
\text { the colony }\end{array}$ \\
\hline $2190(\mathrm{M})$ & $14-04-2007$ & $20-04-2008$ & $23-05-2007$ & $19-12-2007$ & $28-03-2008$ & Chick & Egg & $7 \mathrm{mo}$ \\
\hline $2200(\mathrm{M})$ & 11-04-2007 & $16-04-2008$ & 09-05-2007 & $15-11-2007$ & $15-02-2008$ & Chick & Chick & $6 \mathrm{mo}$ \\
\hline 2204 (M) & $11-04-2007$ & 21-04-2008 & $22-04-2007$ & 23-09-2007 & Non-breeder & $\begin{array}{l}\text { Incubation } \\
\text { failure }^{\mathrm{d}}\end{array}$ & Non-breeder & $5 \mathrm{mo}$ \\
\hline 2207 (?) & $11-04-2007$ & 21-04-2008 & $27-05-2007$ & 03-10-2007 & $11-02-2008$ & Chick & Addled egg & $4 \mathrm{mo}$ \\
\hline
\end{tabular}


logger data. Three of these birds (loggers 2190, 2200 and 2207) had successfully raised a chick while carrying the geolocator and the fourth bird (logger 2204) either failed during incubation or did not attempt to breed. During the chick-rearing period of 2007, between 11 April and 27 May, Barolo shearwaters were tracked for $37.3 \pm 6.7 \mathrm{~d}$ on average (range: 30 to 43 ) with a mean of $66.3 \pm 20.1$ positions per bird (range: 45 to 85 ). The core foraging areas (50\% kernel) during this period were almost exclusively located south of the colony (Fig. 3a) and there was some overlap in the distribution of the 3 breeding birds (Fig. 4a). The bird that failed during incubation still showed some overlap with the breeders in its home range but not in its core area of activity (Fig. 4a). Additionally, it foraged further north, suggesting that chick-rearing restricts the movements of breeders. The home range area $(95 \%$ kernel) used by the 3 chick-rearing individuals exceeded 439000 $\mathrm{km}^{2}$ but the core area of activity (50\% kernel) was much smaller, totaling about $61000 \mathrm{~km}^{2}$. On average, birds spent $77 \%$ of their time during daylight sitting on the water (see Table 9).

During the non-breeding period, between 10 May and 19 December, birds were tracked for a mean of $152.5 \pm 54.3 \mathrm{~d}$ (range: 106 to 209) with a mean of $228.0 \pm 61.5$ positions per bird (range: 152 to 293). Birds dispersed more extensively in all directions but concentrated northwards and eastwards, travelling longer distances (up to $2500 \mathrm{~km}$ ) to the north than to any other direction (Fig. 3b). The area used by the 4 individuals (95\% kernel) exceeded $3250000 \mathrm{~km}^{2}$, but the core area of activity (50\% kernel) was much smaller (about $432000 \mathrm{~km}^{2}$ ). There was also some overlap between the tracked individuals, with the exception of bird 2190, which had a core area much further north (Fig. 4b). During the non-breeding period, Barolo shearwaters spent a high proportion $(89.4 \%)$ of the darkness period on the water and only about $1.2 \mathrm{~h}$ flying (Table 8). During the daytime, the proportion of time spent on the water decreased but was still quite high $(79.7 \%)$ and birds spent on average $2.9 \mathrm{~h}$ flying (Table 8 ).

Birds were very asynchronous regarding the time at which they started visiting the colony again (Table 7). Bird 2204, which failed incubation in 2007, was the first to visit the colony on 7 October 2007 and bird 2190 was the last on 20 December 2007. During the pre-breeding period, birds sporadically visited the colony and still foraged on a spatial scale similar to the non-breeding period, mainly north of the colony (Figs. 3c \& 4c). The core areas of birds 2190 and 2200 were mainly situated within the limits of the Azorean Exclusive Economic Zone (Fig. 4c).

During the pre-breeding period, from 23 September to 10 February, birds were tracked for $89.3 \pm$ $30.3 \mathrm{~d}$ (range: 49 to 115 ) with a mean of $170.0 \pm 57.7$ positions per bird (range: 93 to 222). Again, birds mainly foraged north of the colony but they spent more time there than during the non-breeding period (Fig. 4c). The area used by the 4 individuals exceeded $2000000 \mathrm{~km}^{2}$ but the core area of activity $(50 \%$ kernel) was much smaller, at about $157000 \mathrm{~km}^{2}$ (Fig. 3c). Birds spent on average $76 \%$ of their time during daylight sitting on the water (Table 9).

The incubation and early chick-rearing in 2008 included only movements by 2 males which were incubating or raising a chick upon geolocator recovery, namely birds 2190 and 2200 (of the 2 remaining birds, one - bird 2207 - had failed incubation, and the other - bird 2204 - did not breed in 2008). During the incubation and early chick-rearing periods of 2008, between 11 February and 21 April, the 2 breeding males were tracked for $23.0 \pm 2.8 \mathrm{~d}$ with a mean of $41.0 \pm 8.5$ positions per bird (range: 35 to 47 ). The area used by these 2 individuals exceeded $2320000 \mathrm{~km}^{2}$ but the core area of activity ( $50 \%$ kernel) was much smaller, at about $570000 \mathrm{~km}^{2}$ (Fig. 3d). This was the period when the proportion of time spent flying during the day was highest $(84.1 \%$; Table 9$)$.

Throughout the year, birds mostly targeted areas of

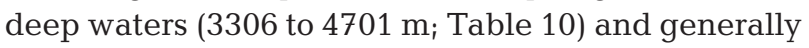
low surface productivity (range: 0.10 to $0.26 \mathrm{mg} \mathrm{m}^{-3}$; Table 10).

Core area size, bathymetry, chl a concentration and SST within the core areas of each individual did not vary significantly between the chick-rearing, nonbreeding and pre-breeding periods (Friedman test, all $0.09 \leq p \leq 0.98$ ). Conversely, home range area seemed to vary more importantly between these periods (Friedman test, $\mathrm{p}=0.039$ ) but these variations were no more significant after sequential Bonferroni correction.

\section{Foraging trip duration}

In 2004, gauge deployment duration equaled foraging trip duration (see above), that is, $1.27 \pm 0.65 \mathrm{~d}$ on average (range: 1 to $3, \mathrm{n}=11$ trips) and $82 \%$ of trips lasted only $1 \mathrm{~d}$. In 2007, geolocators also provided some information on foraging trip duration during chick-rearing, in addition to activity patterns: individual foraging trips in April and May 2007 lasted on average $1.13 \pm 0.34 \mathrm{~d}$ (range: 1 to $2, \mathrm{n}=97$ trips), $87 \%$ of 

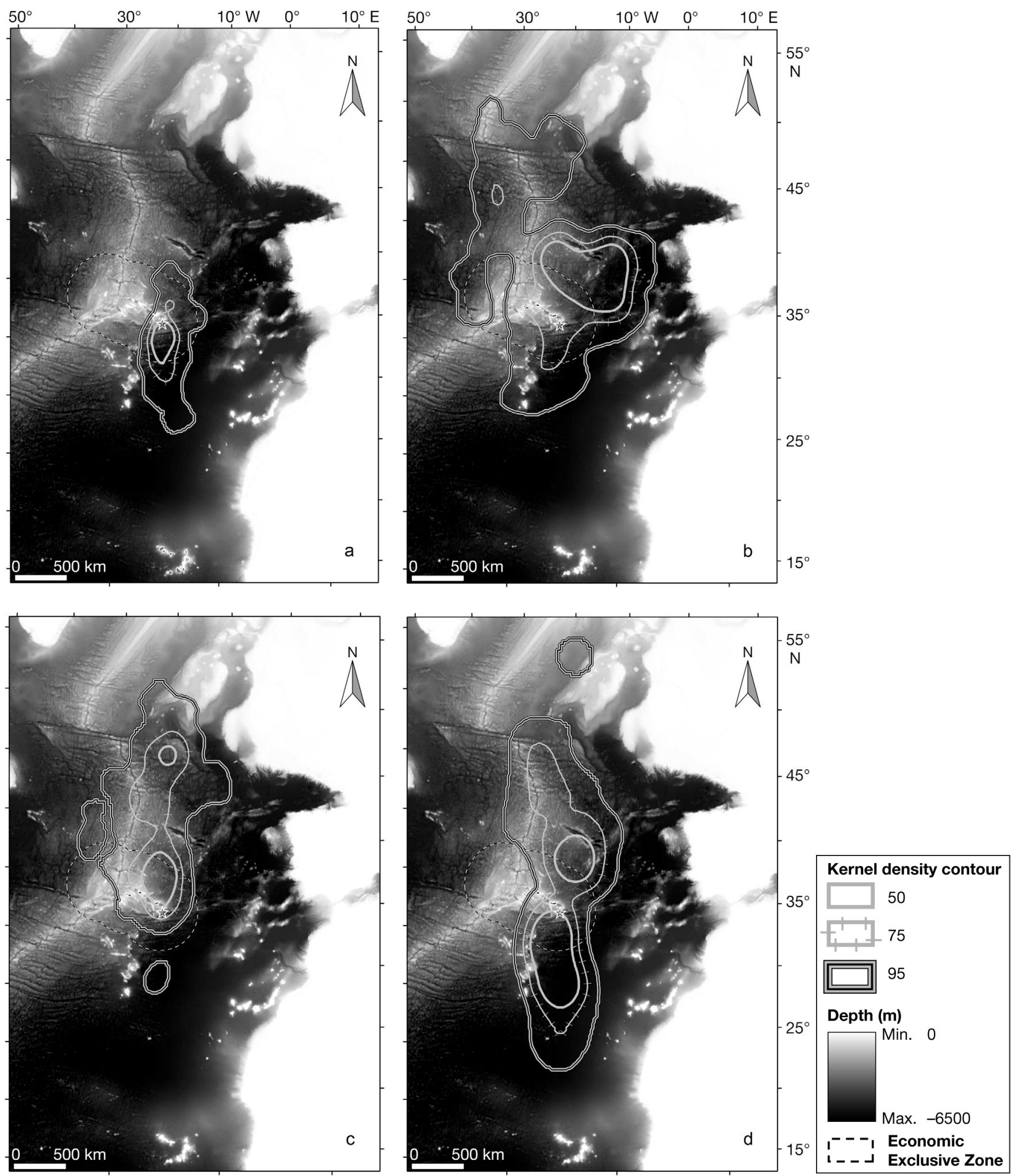

Fig. 3. Puffinus baroli baroli. Density distribution (50\%, $75 \%$ and $95 \%$ kernel contours) of Barolo shearwaters during: (a) the second half of chick-rearing, (b) non-breeding, (c) pre-breeding and (d) incubation and early chick-rearing periods. The colony is marked with a star. Data from all tracked birds combined 

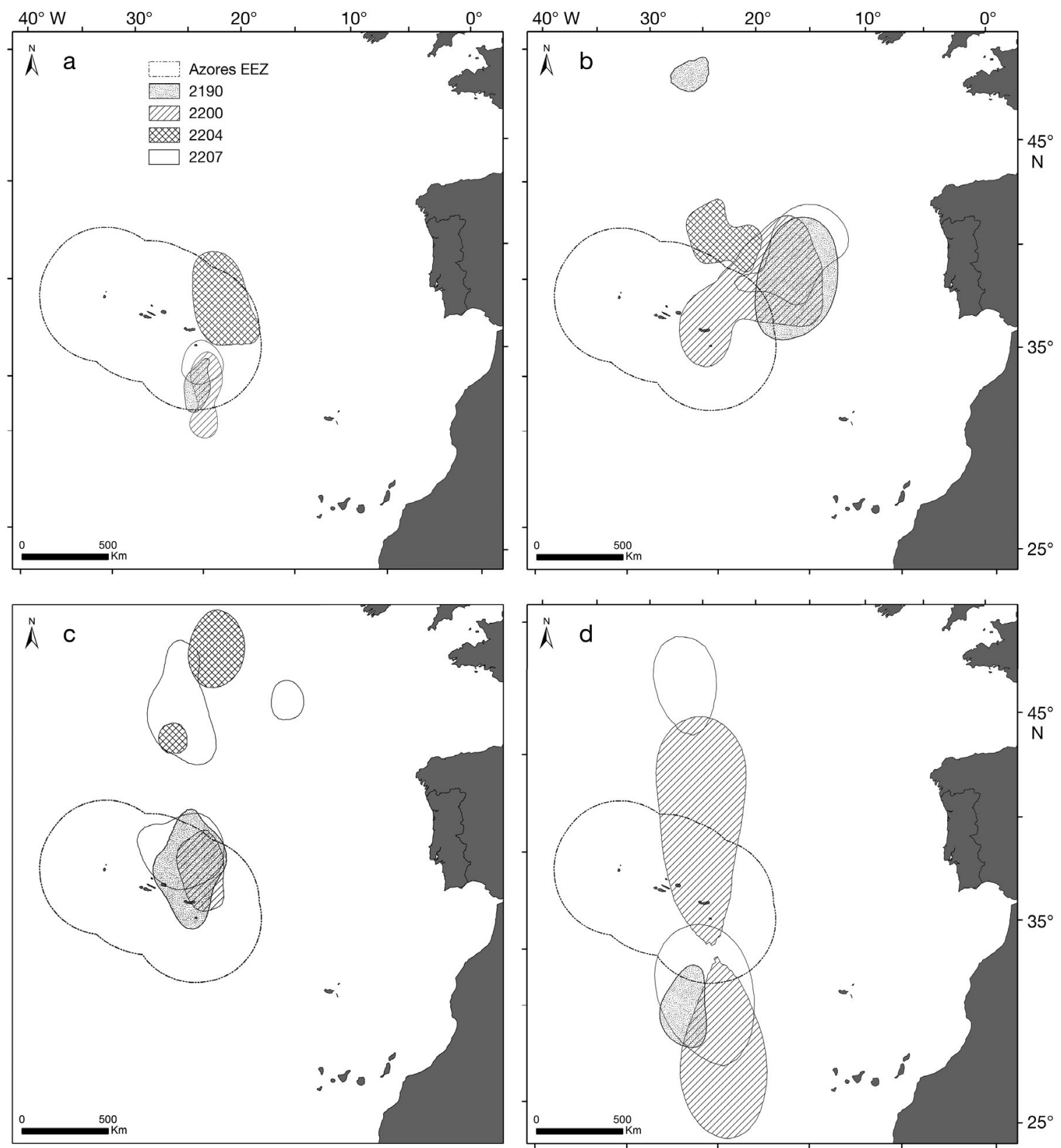

Fig. 4. Puffinus baroli baroli. Density distribution (50\% kernel contours) of Barolo shearwaters during (a) the second half of chick-rearing, (b) non-breeding, (c) pre-breeding and (d) incubation and early chick-rearing periods. Data are presented for each tracked individual. EEZ: Economic Exclusive Zone

Table 8. Puffinus baroli baroli. During the non-breeding period, Barolo shearwaters spend more time on the water than in flight. Values are means \pm SD

\begin{tabular}{|c|c|c|c|c|c|c|}
\hline \multirow{2}{*}{ Individual (sex) } & \multicolumn{2}{|c|}{ Time on water (\%) } & \multicolumn{2}{|c|}{ Total time on water (h) } & \multicolumn{2}{|c|}{ Total time in flight (h) } \\
\hline & Daylight & Darkness & Daylight & Darkness & Daylight & Darkness \\
\hline $2190(\mathrm{M})$ & $79.0 \pm 11.7$ & $91.2 \pm 10.2$ & $10.7 \pm 2.5$ & $9.6 \pm 2.2$ & $2.8 \pm 1.8$ & $0.9 \pm 1.0$ \\
\hline 2200 (M) & $85.1 \pm 10.8$ & $84.7 \pm 18.4$ & $11.9 \pm 2.3$ & $8.3 \pm 1.6$ & $2.0 \pm 1.4$ & $1.8 \pm 2.2$ \\
\hline 2204 (M) & $75.6 \pm 15.1$ & $87.8 \pm 18.6$ & $11.4 \pm 2.7$ & $7.8 \pm 1.5$ & $3.6 \pm 2.1$ & $1.2 \pm 1.9$ \\
\hline $2207(?)$ & $79.0 \pm 13.1$ & $93.7 \pm 10.6$ & $11.6 \pm 2.5$ & $8.7 \pm 1.2$ & $3.0 \pm 1.7$ & $0.7 \pm 1.2$ \\
\hline Mean & $79.7 \pm 14.4$ & $89.4 \pm 15.5$ & $11.4 \pm 2.8$ & $8.6 \pm 1.4$ & $2.9 \pm 1.8$ & $1.2 \pm 1.8$ \\
\hline
\end{tabular}


Table 9. Puffinus baroli baroli. Birds spend more time on the water than in flight during the chick-rearing, pre-breeding and incubation periods. Values are means \pm SD. Only values for daylight are included since during darkness it is not possible to distinguish between flight and nest attendance. CR: Chick-rearing; PB: Pre-breeding; Incub.: Incubation

\begin{tabular}{|c|c|c|c|c|c|c|c|c|c|}
\hline \multirow{2}{*}{$\begin{array}{l}\text { Individual } \\
\text { (sex) }\end{array}$} & \multicolumn{3}{|c|}{ Time on water (\%) } & \multicolumn{3}{|c|}{ Total time on water (h) } & \multicolumn{3}{|c|}{ Total time in flight (h) } \\
\hline & $\mathrm{CR}$ & PB & Incub. & $\mathrm{CR}$ & $\mathrm{PB}$ & Incub. & $\mathrm{CR}$ & PB & Incub. \\
\hline $2190(\mathrm{M})$ & $80.7 \pm 5.5$ & $79.7 \pm 12.2$ & $85.0 \pm 6.6$ & $11.5 \pm 0.8$ & $8.9 \pm 1.7$ & $11.4 \pm 0.9$ & $2.8 \pm 0.8$ & $2.2 \pm 1.2$ & $2.0 \pm 0.9$ \\
\hline 2200 (M) & $80.2 \pm 7.1$ & $91.0 \pm 6.5$ & $90.9 \pm 6.4$ & $11.2 \pm 1.1$ & $9.6 \pm 0.8$ & $11.4 \pm 0.8$ & $2.8 \pm 0.9$ & $1.1 \pm 1.2$ & $1.2 \pm 0.8$ \\
\hline 2204 (M) & $71.6 \pm 8.3^{\mathrm{a}}$ & $65.2 \pm 16.9^{\mathrm{b}}$ & - & $9.7 \pm 1.0$ & $6.8 \pm 2.0$ & - & $3.9 \pm 1.2$ & $3.6 \pm 1.8$ & - \\
\hline 2207 (?) & $75.1 \pm 8.2$ & $68.1 \pm 16.8$ & $76.5 \pm 12.4^{\mathrm{c}}$ & $10.7 \pm 1.3$ & $7.0 \pm 1.6$ & $9.4 \pm 1.7$ & $3.6 \pm 1.2$ & $3.3 \pm 1.8$ & $2.8 \pm 1.4$ \\
\hline Mean & $76.9 \pm 7.3$ & $76.0 \pm 13.1$ & $84.1 \pm 8.5$ & $10.8 \pm 1.1$ & $8.1 \pm 1.5$ & $10.7 \pm 1.1$ & $3.3 \pm 1.0$ & $2.6 \pm 1.0$ & $2.0 \pm 1.0$ \\
\hline
\end{tabular}

aCorresponds to the period between 12 and 22 April 2007, after that the bird abandoned the nest. The data refers to incubation since this bird did not have a chick; ${ }^{\mathrm{b}}$ Corresponds to the period from when the bird started visiting the colony $(23$ September 2007) until the logger stopped recording activity data (21 February 2008). At this time, the bird had not started

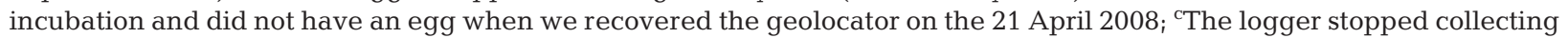
activity data on the 31 March 2008

Table 10. Puffinus baroli baroli. Barolo shearwater targeted areas of deep waters and generally low surface productivity. Birds used in each stage in brackets. Values are means \pm SD. $\mathrm{SST}=$ sea surface temperature. Areas of the $50 \%$ and $95 \%$ kernels are presented in Fig. 3

\begin{tabular}{|c|c|c|c|}
\hline $\begin{array}{l}\text { Breeding } \\
\text { stage }\end{array}$ & $\begin{array}{c}\text { Water } \\
\text { depth (m) }\end{array}$ & $\begin{array}{l}\text { Chl a concen- } \\
\text { tration }\left(\mathrm{mg} \mathrm{m}^{-3}\right)\end{array}$ & $\mathrm{SST}\left({ }^{\circ} \mathrm{C}\right)$ \\
\hline \multicolumn{4}{|c|}{ Chick-rearing $(2190,2200,2207)$} \\
\hline $50 \%$ kernel & $4355 \pm 805$ & $0.10 \pm 0.02$ & $18.9 \pm 0.7$ \\
\hline $95 \%$ kernel & $4701 \pm 898$ & $0.10 \pm 0.04$ & $19.6 \pm 1.0$ \\
\hline \multicolumn{4}{|c|}{ Non-breeding $(2190,2200,2204,2207)$} \\
\hline $50 \%$ kernel & $4133 \pm 771$ & $0.18 \pm 0.09$ & $18.5 \pm 1.7$ \\
\hline $95 \%$ kernel & $3689 \pm 1034$ & $0.25 \pm 0.23$ & $17.7 \pm 3.6$ \\
\hline \multicolumn{4}{|c|}{ Pre-breeding $(2190,2200,2204,2207)$} \\
\hline $50 \%$ kernel & $3306 \pm 673$ & $0.24 \pm 0.08$ & $17.0 \pm 2.4$ \\
\hline $95 \%$ kernel & $3371 \pm 889$ & $0.24 \pm 0.11$ & $15.3 \pm 2.7$ \\
\hline \multicolumn{4}{|c|}{ Incubation and early-chick rearing $(2190,2200)$} \\
\hline $50 \%$ kernel & $3734 \pm 1186$ & $0.26 \pm 0.16$ & $16.9 \pm 2.2$ \\
\hline $95 \%$ kernel & $4004 \pm 1158$ & $0.22 \pm 0.15$ & $17.6 \pm 3.3$ \\
\hline
\end{tabular}

them being single-day trips. On average, however, individuals did not perform significantly longer trips in 2004 than in 2007 (Mann-Whitney $U=5, N_{1}=6$, $\mathrm{N}_{2}=3, \mathrm{p}>0.2$ ). Additionally, in 2008, geolocators provided some information on the durations of incubation shifts and foraging trips during incubation, which were $6.2 \pm 2.4 \mathrm{~d}$ (range: 3 to $10, \mathrm{n}=6$ trips) and $6.3 \pm 2.4$ d (range: 3 to $9, \mathrm{n}=6$ trips), respectively.

\section{DISCUSSION}

This is the first detailed study on the feeding ecology of the Barolo shearwater merging information on diet, trophic level, diving ability, foraging movements and at-sea activity patterns.

\section{Diving abilities, activity patterns and diet composition}

Maximum depth gauges showed that Barolo shearwaters exploit the upper $15 \mathrm{~m}$ of the water column during chick-rearing. On average, the maximum dive depths of this species were much greater than those reached by other small Azorean Procellariiformes (Bulwer's petrel Bulweria bulwerii: $2.4 \mathrm{~m}$, Mougin \& Mougin 2000; Monteiro's storm-petrel Oceanodroma monteiroi: $0.85 \mathrm{~m}$, Bried 2005), but they were similar to those of its close relative Audubon's shearwater Puffinus lherminieri $(15 \mathrm{~m}$, Burger 2001). Burger (2001) also showed that the absolute maximum depths reached by Puffinus shearwaters equipped with MDGs were close to those predicted by his allometric equation for penguins and alcids (Burger 1991). According to this equation, the $172 \mathrm{~g}$ (value obtained by Monteiro et al. 1996 from 157 individuals, close to that obtained in this study) Barolo shearwater should be able to reach $43.5 \mathrm{~m}$ underwater. The absolute maximum depth recorded here was $23.1 \mathrm{~m}$, that is, about half the predicted value, and well below the $35 \mathrm{~m}$ recorded for the $168 \mathrm{~g}$ Audubon shearwater (Burger 2001). These results suggest that Barolo shearwaters might have a limited diving capacity compared to other shearwater species, or that they do not need to dive as deep as they could to find their prey during the chick-rearing period. Barolo shearwaters are thought to be mainly diurnal at sea but activity data during the non-breeding period show that birds spend most of the time resting on the sea surface during both night and day. On average, the amount of time that birds spent in the water during daylight exceeded $75 \%$, a value about $20 \%$ higher than that 
found for the congeneric wedge-tailed shearwater $P$. pacificus (Catry et al. 2009). Indeed, activity patterns during the non-breeding period showed that Barolo shearwaters do not have a marked diurnal or nocturnal cycle but they may forage both in darkness and in daylight conditions, although birds showed a slightly greater tendency to fly during daytime.

The cephalopods Argonauta argo, Tremoctopus violaceus, and very small Onychia/Onychoteuthis sp., Liocranchia reinhardti and Todarodes sagittatus are known to come near the surface (to the upper $50 \mathrm{~cm}$ ) at night (M. R. Clarke pers. obs.), although adults are usually found at greater depths. During the day, these species are not sampled at the surface by conventional methods but it is likely that they move to the surface at twilight, shortly after sunset. The squid Histioteuthis $A$ and Taonius pavo are also considered to live at greater depths but our results indicate that the juveniles of these species may come to the surface. The lower hood length of beaks of adult $A$. argo varies between 3 and $5 \mathrm{~mm}$ (Clarke 1986), but that of the $A$. argo consumed by Barolo shearwaters in the Azores was generally shorter than $1.5 \mathrm{~mm}$, indicating birds were feeding on juveniles. The dietary spectrum of Barolo shearwaters in the Azores showed a considerable diversity of cephalopods, including representatives of 6 families. On the Hawaiian Islands, Harrison et al. (1983) showed that wedge-tailed shearwaters and Christmas shearwaters Puffinus nativitatis mainly fed on squid of the Omastrephidae family ( $99 \%$, by number of identified squid) but some Octopoda and Onychoteutidae were also consumed. However, the frequency of occurrence of squid was only $28 \%$ in the diet of short-tailed shearwaters $P$. tenuirostris in Tasmania (Skira 1986). In wedge-tailed shearwaters and Christmas shearwaters, squid accounted for $29 \%$ and $48 \%$ of the total volume of ingested prey, respectively. It remains unknown whether this reflects higher versatility from Barolo shearwaters, a higher diversity of the cephalopod prey available in the Azores area, or both. A. argo has been found in the stomachs of longnose lancetfish Alepisaurus ferox, dolphinfish Coryphaena hippurus (Clarke 1986), swordfish Xiphias gladius from the eastern Mediterranean (Bello 1991) and from the Azores region (Clarke et al. 1995) and also blue shark Prionace glauca from the Azores (Clarke et al. 1996). A. argo was the most abundant cephalopod in the stomachs of Barolo shearwaters and was also the most abundant cephalopod prey (occurrence $=18 \%$ ) found in stomachs of swordfish in the Azores (Clarke et al. 1995), suggesting that this species might be common around the archipelago.
Similarly to Barolo shearweaters, the Bulwer's petrels from the Azores also feed on a high diversity of small cephalopods (Neves et al. 2011). Previous studies of the diet of Cory's shearwater in the Azores (Granadeiro et al. 1998) found a smaller contribution of cephalopods than we did here, both in terms of occurrence $(\mathrm{FO}=24 \%)$ and number $(\mathrm{NF}=4.4 \%)$. Conversely, the frequency of occurrence of squid in the diet of Barolo shearwaters exceeded $90 \%$. The large occurrence and diversity of small squid in their diet, together with the fact that they may forage by day and by night, strongly suggest that Barolo shearwaters are able to exploit the diel vertical migration of these prey, feeding extensively when juvenile cephalopods move up to the epipelagic zone at night. Our study also confirms that seabirds are amongst the best samplers of cephalopod populations currently available (Croxall \& Prince 1996). In this regard, the wide variety and the inter-annual changes in the squid composition found in the diet of the Barolo shearwater indicates its potential usefulness for monitoring the Azores squid community.

Concerning fish prey, Phycis sp. of the size range found in Barolo shearwater stomachs (max. size $<60 \mathrm{~mm}$ ) have never been caught by scientific cruises in the Azores, the smallest individual caught being $150 \mathrm{~mm}$ long (J. Fontes pers. comm.). Mature $P$. phycis females are found from October to February (Â. Canha pers. comm.), so it is possible that the small Phycidae found in Barolo shearwater stomachs in late March resulted from recent spawning. The low diversity of fish prey found in Barolo shearwater stomachs may be a true reflection of their diet but may also be due to the fact that this seabird feeds on small prey with small otoliths that are easily digested and often not detected in the diet samples. In fact, only 17 out of 51 samples with fish remains also contained otoliths. This limitation, typical of conventional dietary studies, suggests the diet composition presented above represents minimum values of prey richness. Additionally, the lower number of otoliths found in 2000 may be a reflection of otolith digestion and not a true indicator of a decrease in fish numbers; despite the fact that fish was present in $52 \%$ of samples, otoliths only appeared in $6 \%$ of samples.

\section{Trophic level and trophic niche}

Overall, the main prey species found in the diet of the Barolo shearwater were very small epipelagic squid and fish species, which together with low nitrogen values in their feathers confirm that these shear- 
waters are the seabirds with the lowest trophic level in the NE Atlantic (Roscales et al. 2011a). These findings are consistent with previous studies based on biomagnificative contaminants (whose concentration in tissues or feathers tends to increase with trophic level), which showed that mean mercury and persistent organic pollutant (POP) concentrations in the breast feathers and blood of Barolo shearwaters, respectively, were the lowest amongst the Azorean Procellariiformes (Monteiro 1996, Roscales et al. 2011b). Moreover, Barolo shearwaters showed a broader range of variation for both $\delta^{13} \mathrm{C}$ and $\delta^{15} \mathrm{~N}$ compared to the 2 storm petrels Oceanodroma spp. and Cory's shearwaters breeding in Azores (Bolton et al. 2008, Roscales et al. 2011a). This result is consistent with the broad prey spectrum found in the diet and probably reflects the ability of Barolo shearwaters to exploit a greater portion of the water column compared to many other Azorean seabirds as well as to feed both by day and by night. When comparing the results of geolocators to those of stable isotopes we found no relationship between $\delta^{15} \mathrm{~N}$ or $\delta^{13} \mathrm{C}$ and foraging areas. This result is not surprising given that isotopic landscapes in the NE Atlantic context are relatively homogeneous, especially among the northern Macaronesian archipelagos (Graham et al. 2010, Roscales et al. 2011a). Given that Barolo shearwaters do not migrate far from their colonies and their feeding areas at the end of the breeding period widely overlap with those exploited during the non-breeding period (Fig. 4), the consistent increase in nitrogen values from P1 to S8 over 3 yr probably indicates a dietary switch from the breeding to the non-breeding period, when these feathers are respectively thought to be grown. Alternatively, these changes in the isotopic signatures may reflect seasonal changes in baseline values. Nevertheless, some dietary changes are expected as seasonal changes in baseline stable isotope values within the north Atlantic levels are markedly lower than those we found between P1 and S8 (Montoya et al. 2002). The enrichment of $\delta^{15} \mathrm{~N}$ in S8 suggests a higher trophic level during the nonbreeding period, which may indicate a more selective foraging on larger prey, related to an unconstrained foraging range out of the breeding period or to a selection of smaller prey for chick feeding during the breeding period (Badalamenti et al. 2002, Cherel \& Hobson 2005). In the present study, stable isotopic values of P1 and S8 also showed significant differences among years due to the anomalous $\delta^{15} \mathrm{~N}$ and $\delta^{13} \mathrm{C}$ values found in 2008. It is difficult to explain the higher $\delta^{15} \mathrm{~N}$ and lower $\delta^{13} \mathrm{C}$ values obtained in 2008 for P1 and S8, respectively. Given that Barolo shear- waters perform short foraging trips during chickrearing it is hard to conceive that they could afford to exploit different isotopic landscapes from one year to the next. These values could be due to stochastic abundance and availability of a given prey with different isotopic values than the common prey or to differences in the baseline values of carbon and nitrogen isotopes in 2008 caused by changes in water mass driven by climate or oceanography.

\section{Seasonal distribution at sea}

On Vila islet, adults visited their nests on most nights during the chick-rearing period. Our results therefore confirm those of Hamer (1994) on Selvagem Grande, situated ca. $1100 \mathrm{~km}$ from Vila islet, where Barolo shearwater chicks received food from their parents on $95 \%$ of nights. High visitation rates have also been observed in other small shearwaters: chicks of Puffinus assimilis assimilis were visited by one or both parents during $94 \%$ of nights (Priddel et al. 2003), P. a. haurakiensis chicks were fed during $90 \%$ of nights (Booth et al. 2000) and P. a. kermadecensis chicks were visited by 1 or both parents each night (Warham 1955). Overall, these results suggest all 'little' shearwaters mostly forage close to their breeding colony when rearing their chicks. This was confirmed by the geolocator data concerning the second half of the chick-rearing period, which showed that core foraging areas were located at relatively close proximity to the colony, and by the duration of the foraging trips, most of which lasted only $1 \mathrm{~d}$. The absence of oil in the stomachs of Barolo shearwaters, which suggests that adults deliver fresh meals to their chicks, was also consistent with these findings. Interestingly, the birds from Vila islet seemed to target oceanic areas with very deep bathymetry even if they had seamounts and higher productivity areas within reach (Tempera et al. 2009). Similarly, wedgetailed shearwaters also forage over deep, warm and relatively unproductive oceanic waters in the Indian Ocean (Catry et al. 2009). This habitat segregation possibly minimizes competition with the larger and more abundant Cory's shearwater, which forages mostly in low depth (i.e. seamounts) and productive seascapes in the Azores (Magalhães et al. 2008, Paiva et al. 2010b). During incubation, Barolo shearwaters seemed to forage over a considerably larger area than during chick-rearing, and the duration of the foraging trips was also longer during incubation than during chick-rearing. Foraging trips have also been shown to be longer on average during incubation 
than during chick-rearing in several procellariiform species (e.g. wandering albatross Diomedea exulans, Weimerskirch et al. 1993; Cory's shearwater, Paiva et al. 2010a,c; white-chinned petrel Procellaria aequinoctialis, Berrow et al. 2000).

During the non-breeding period, Barolo shearwaters increased their core foraging area 10-fold (up to $2500 \mathrm{~km}$ from the colony) compared with the chickrearing period, but overall they remained in the north Atlantic region, confirming previous hypotheses (Monteiro et al. 1996) that this species does not perform large-scale migrations. In contrast, the Azorean populations of Cory's shearwaters (González-Solís et al. 2007a), Bulwer's petrels (J. González-Solís unpubl. data), common terns Sterna hirundo and roseate terns S. dougallii (Hays et al. 2002, Neves et al. 2002) overwinter in the southern Atlantic. The only other Azorean petrel that may remain in the Azorean waters throughout the year is the endemic Monteiro's storm-petrel (Bolton et al. 2008).

Overall, our results illustrate how integrating different methods increases understanding of the feeding ecology and foraging behaviour of an elusive species and indicate that the Barolo shearwater feeds on a diverse spectrum of small squid and fish of low trophic level, during both day and night, on areas with a deep bathymetry and in a relatively large portion of the water column. The contrasting foraging ecology of this species when compared to the other Azorean Procellariiformes confirms the existence of an important degree of ecological segregation within the seabird community from the Azores (Roscales et al. 2011a). In this regard, the sharp differences in the exploited areas highlight the need to consider the movements of several seabird species with a wide range of ecological requirements when defining important bird areas at sea.

Acknowledgements. This work was co-financed by the Portuguese Foundation for Science and Technology (research contracts PRAXIS/2/2.1/MAR/1680/95 and grant PRAXIS/ XXI/BIC/17094/98 and FCT/BPD/26657/2006 to V.C.N., grants IMAR/FCT-PDOC-001/2001-BirdECo and FRH/BPD/ 20291/2004 to J.B.), by POCI 2010 and FSE, and by the Ministerio de Ciencia e Innovación and Fondos FEDER (CGL2009-11278/BOS). Fieldwork was funded by the Programmes 'OGAMP' (Planning and Management of Marine Protected Areas, Interreg IIIB-MAC/4.2/A2), and 'MARMAC' (Knowledge, Promotion and Valorization for a Sustainable Utilization of Marine Protected Areas in Macaronesia, Interreg IIIB-05/FEDER/MAC/4.2/A4). IMAR-DOP/UAç is funded through the pluri-annual and programmatic funding schemes of FCT and DRCT (Azores, Portugal) as Research Unit No. 531 and Associate Laboratory No. 9. Thanks to R. Medeiros for help with Figs. 3 \& 4 . We thank A. Mendes, A. Paixão, A. Tavares, J. Pereira, M. Carvalho, M.
Laranjo, P. Pedro and R. Ceia for field assistance, as well as the Clube Naval of Santa Maria (especially M. Cabral) and J. M. Soares and his family for transport to Vila Islet. Finally we thank B. Zonfrillo and 4 anonymous referees whose useful suggestions greatly improved the manuscript. This study would not have been possible without L. Monteiro, who died in a plane accident before the fieldwork was concluded. The experimental procedure complied with the Portuguese law and was conducted under licenses Nos. 1/98 and 1/CN/2004 issued by the Direcção Regional do Ambiente from the Azores.

\section{LITERATURE CITED}

Badalamenti F, D'Anna G, Pinnegar JK, Polunin NVC (2002) Size-related trophodynamic changes in three target fish species recovering from intensive trawling. Mar Biol 14: 561-570

Barrett RT, Camphuysen CJ, Anker-Nilssen T, Chardine JW and others (2007) Diet studies of seabirds: a review and recommendations. ICES J Mar Sci 64:1675-1691

Bello G (1991) Role of cephalopods in the diet of the swordfish Xiphias gladius, from the Eastern Mediterranean Sea. Bull Mar Sci 49:312-324

Berrow SD, Wood AG, Prince PA (2000) Foraging location and range of white-chinned petrels Procellaria aequinoctialis breeding in the South Atlantic. J Avian Biol 31: 303-311

BirdLife International (2004) Birds in Europe: population estimates, trends and conservation status. BirdLife International, Cambridge

> Bocher P, Labidoire B, Cherel Y (2000) Maximum dive depths of common diving petrels (Pelecanoides urinatrix) during the annual cycle at Mayes Island, Kerguelen. J Zool (Lond) 251:517-524

Bolton M, Smith AL, Gómez-Díaz E, Friesen VL and others (2008) Monteiro's storm-petrel Oceanodroma monteiroi: a new species from the Azores. Ibis 150:717-727

Booth AM, Minot EO, Fordham RA, Imber MJ (2000) Coordinated food provisioning in the little shearwater Puffinus assimilis haurakiensis: a previously undescribed foraging strategy in the Procellariidae. Ibis 142:139-158

Bried J (2005) Diving ability of the Madeiran storm petrel. Waterbirds 28:162-166

Brooke ML (2004a) Albatrosses and petrels across the world. Oxford University Press, Oxford

Brooke ML (2004b) The food consumption of the world's seabirds. Biol Lett 271:246-248

Burger AE (1991) Maximum diving depths and underwater foraging in alcids and penguins. In: Montevecchi WA Gaston AJ (eds) Studies of high latitude seabirds 1. Behavioural, energetic and oceanographic aspects of seabird feeding ecology. Canadian Wildlife Service Occasional Paper 68, p 9-15

> Burger AE (2001) Diving depths of shearwaters. Auk 118: 755-759

> Burger AE, Shaffer SA (2008) Application of tracking and data-logging technology in research and conservation of seabirds. Auk 125:253-264

Burger AE, Wilson RP (1988) Capillary tube depth gauges for diving animals: an assessment of their accuracy and their applicability. J Field Ornithol 59:345-354

Campbell JW, Blaisdell JM, Darzi M (1995) Level-3 SeaWiFS data products: spatial and temporal binning algo- 
rithms. In: Hooker SB, Firestone ER, Acker, JG (eds) NASA Tech Memo 104566, Vol 32. NASA Goddard Space Flight Center, Greenbelt, MD, 1-80

Catry T, Ramos JA, Le Corre M, Phillips RA (2009) Movements, at-sea distribution and behaviour of a tropical pelagic seabird: the wedge-tailed shearwater in the western Indian Ocean. Mar Ecol Prog Ser 391:231-242

$>$ Cherel Y, Hobson KA (2005) Stable isotopes, beaks and predators: a new tool to study the trophic ecology of cephalopods, including giant and colossal squids. Proc Biol Sci 272:1601-1607

Clarke MR (1986) A handbook of identification of cephalopod beaks. Clarendon Press, Oxford

Clarke MR, Clarke DC, Martins HR, Silva HM (1995) The diet of swordfish (Xiphias gladius) in Azorean waters. Arquipél Life Mar Sci 13:53-56

Clarke MR, Clarke DC, Martins HR, Silva HM (1996) The diet of the blue shark (Prionace glauca L.) in Azorean waters. Arquipél Life Mar Sci 14:41-56

> Connan M, Mayzaud P, Trouvé C, Barbraud C, Cherel Y (2008) Interannual dietary changes and demographic consequences in breeding blue petrels from Kerguelen Islands. Mar Ecol Prog Ser 373:123-135

Croxall JP, Prince PA (1996) Cephalopods as prey: seabirds. Philos Trans R Soc Lond B 351:1023-1043

DeNiro MJ, Epstein S (1978) Influence of diet on the distribution of carbon isotopes in animals. Geochim Cosmochim Acta 42:495-506

DeNiro MJ, Epstein S (1981) Influence of diet on the distribution of nitrogen isotopes in animals. Geochim Cosmochim Acta 45:341-351

Forero MG, Bortolotti GR, Hobson KA, Donazar JA, Bertelloti M, Guillermo B (2004) High trophic overlap within the seabird community of Argentinean Patagonia: a multiscale approach. J Anim Ecol 73:789-801

- France RL (1995) Differentiation between littoral and pelagic food webs in lakes using carbon isotopes. Limnol Oceanogr 40:1310-1313

Fridolfsson AK, Ellegren H (1999) A simple and universal method for molecular sexing of non-ratite birds. J Avian Biol 30:116-121

Fry B (2006) Stable isotope ecology. Springer, New York, NY

Furness R, Laugksch LRC, Duffy DC (1984) Cephalopod beaks and the study of seabird diets. Auk 101:619-620

González-Solís J, Croxall JP, Oro D, Ruiz X (2007a) Transequatorial migration and mixing in the wintering areas in a pelagic seabird. Front Ecol Environ 5:297-301

González-Solís J, Croxall JP, Afanasyev V (2007b) Offshore spatial segregation in giant petrels Macronectes spp.: differences between species, sexes and seasons. Aquat Conserv 17:S22-S36

Graham BS, Koch PL, Newsome SD, McMahon KW, Aurioles D (2010) Using isoscapes to trace the movements and foraging behavior of top predators in oceanic ecosystems. In: West JB, Bowen GJ, Tawson DE, Tu KP (eds) Isoscapes: understanding movement, pattern, and process on earth through isotope mapping. Springer, New York, NY, p 299-318

Granadeiro JP, Monteiro LR, Furness RW (1998) Diet and feeding of Cory's shearwater Calonectris diomedea in the Azores, north-east Atlantic. Mar Ecol Prog Ser 166: $267-276$

> Hamer KC (1994) Variability and stochasticity of meal size and feeding frequency in the little shearwater Puffinus assimilis. Ibis 136:271-278
Härkönnen TJ (1986) Guide to the otoliths of the bony fishes of the northeast Atlantic. Danbiu ApS. Biological consultants, Hellerup

Harrison CS, Hida S, Seki M (1983) Hawaiian seabird feeding ecology. Wildl Monogr 85:1-71

Hays H, Neves VC, Lima P (2002) Banded roseate terns from different continents trapped in the Azores. J Field Ornithol 73:180-184

Hobson KA (1999) Tracing origins and migration of wildlife using stable isotopes: a review. Oecologia 120:314-326

Hobson KA, Clark RG (1992a) Assessing avian diets using stable isotopes II: factors influencing diet-tissue fractionation. Condor 94:189-197

Hobson KA, Clark RG (1992b) Assessing avian diets using stable isotopes I: turnover of ${ }^{13} \mathrm{C}$ in tissues. Condor 94 : 181-188

Hobson KA, Welch HE (1992) Determination of trophic relationships within a high Arctic marine food web using $\delta^{13} \mathrm{C}$ and $\delta^{15} \mathrm{~N}$ analysis. Mar Ecol Prog Ser 84:9-18

> Hobson KA, Piatt JF, Pitocchelli J (1994) Using stable isotopes to determine seabird trophic relationships. J Anim Ecol 63:786-798

Jackson S, Ryan PG (1986) Differential digestion rates of prey by white-chinned petrels (Procellaria aequinoctialis). Auk 103:617-621

Karpouzi VS, Watson R, Pauly D (2007) Modelling and mapping resource overlap between seabirds and fisheries on a global scale: a preliminary assessment. Mar Ecol Prog Ser 343:87-99

Kelly JF (2000) Stable isotopes of carbon and nitrogen in the study of avian and mammalian trophic ecology. Can J Zool 78:1-27

Lombarte A, Chic Ò, Parisi-Baradad V, Olivella R, Piera J, Garcá-Ladona E (2006) A web-based environment for shape analysis of fish otoliths, The AFORO database. Sci Mar 70:147-152

Magalhães MC, Santos RS, Hamer KC (2008) Dual-foraging strategy of Cory's shearwaters in the Azores: feeding locations, behaviour at sea and implications for food provisioning of chicks. Mar Ecol Prog Ser 359:283-293

> Minagawa M, Wada E (1984) Stepwise enrichment of ${ }^{15} \mathrm{~N}$ along food chains: further evidence and the relation between $\delta^{15} \mathrm{~N}$ and animal age. Geochim Cosmochim Acta 48:1135-1140

Monteiro LR (1996) Seabirds as monitors of mercury contamination in the Portuguese Atlantic. PhD thesis, University of Glasgow

> Monteiro LR, Ramos JA, Furness RW (1996) Movements, morphology, breeding, molt, diet and feeding of seabirds in the Azores. Colon Waterbirds 19:82-97

Monteiro LR, Ramos JA, Pereira JC, Monteiro PR and others (1999) Status and distribution of Fea's petrel, Bulwer's petrel, Manx shearwater, little shearwater and bandrumped storm-petrel in the Azores archipelago. Waterbirds 22:358-366

> Montoya JP, Carpenter EJ, Capone DG (2002) Nitrogen fixation and nitrogen isotope abundances in zooplankton of the oligotrophic north Atlantic. Limnol Oceanogr 47: 1617-1628

Mougin JL, Mougin MC (2000) Maximum diving depths for feeding attained by Bulwer's petrels (Bulweria bulwerii) during the incubation period. J Zool (Lond) 250:75-77

Nesis K (1987) Cephalopods of the world. TNP Publications, New York, NY

> Neves VC, Bremer E, Hays H (2002) Recovery in Punta Rasa, 
Argentina of common terns banded in the Azores Archipelago, North Atlantic. Waterbirds 25:459-461

Neves VC, Bolton M, Monteiro LR (2006) Validation of the water offloading technique for diet assessment: an experimental study with Cory's shearwaters Calonectris diomedea. J Ornithol 147:474-478

Neves V, Nolf D, Clarke MR (2011) Diet of Bulwer's petrel (Bulweria bulwerii) in the Azores, NE Atlantic. Waterbirds 34:357-362

Nolf D (1985) Otolithi Piscium. Handbook of paleoichthyology, Vol 10. Gustav Fisher Verlag, New York, NY

Owens NJP (1987) Natural variations in ${ }^{15} \mathrm{~N}$ in the marine environment. Adv Mar Biol 24:389-451

Paiva VH, Geraldes P, Ramírez I, Meirinho A, Garthe S, Ramos JA (2010a) Foraging plasticity in a pelagic seabird species along a marine productivity gradient. Mar Ecol Prog Ser 398:259-274

Paiva VH, Geraldes P, Ramírez I, Meirinho A, Ramos JA, Garthe S (2010b) Oceanographic characteristics of areas used by Cory's shearwaters during short and long foraging trips in the North Atlantic. Mar Biol 157:1385-1399

Paiva VH, Xavier J, Geraldes P, Ramírez I, Meirinho A, Ramos JA, Garthe S (2010c) Foraging ecology of Cory's shearwaters in different ecological environments of the North Atlantic. Mar Ecol Prog Ser 410:257-268

Passos C, Giudici A, Navarro J, González-Solís J (2010) Effects of an experimental mass increase on the foraging activity of Cory's shearwaters. Auk 127:100-107

Petry MV, Fonseca VSS, Garcia LK, Piuco RC (2008) Shearwater diet during migration along the coast of Rio Grande do Sul. Mar Biol 154:613-621

Phillips RA, Silk JRD, Croxall JP, Afanasyev V, Briggs DR (2004) Accuracy of geolocation estimates for flying seabirds. Mar Ecol Prog Ser 266:265-272

Priddel D, Hutton I, Carlile N, Bester A (2003) Little shearwaters, Puffinus assimilis assimilis, breeding on Lord Howe Island. Emu 103:67-70

Ramos R, González-Solís J (2012) Trace me if you can: reviewing the usage of intrinsic biogeochemical markers in marine top predators. Front Ecol Environ, in press

Rau GH, Sweeney RE, Kaplan IR (1982) Plankton ${ }^{13} \mathrm{C} /{ }^{12} \mathrm{C}$ change with latitude: differences between northern and southern. Deep-Sea Res I 29:1035-1039

Ridoux V (1994) The diets and dietary segregation of

Editorial responsibility: Rory Wilson,

Swansea, UK seabirds at the subantarctic Crozet islands. Mar Ornithol 22:1-192

Roberts JJ, Best BD, Dunn DC, Treml EA, Halpin PN (2010) Marine geospatial ecology tools: an integrated framework for ecological geoprocessing with ArcGIS, Python, R, MATLAB, and C++. Environ Model Softw 25: 1197-1207

Roscales JL, Gómez-Díaz E, Neves V, González-Solís J (2011a) Trophic versus geographic structure in stable isotope signatures of pelagic seabirds breeding in the northeast Atlantic. Mar Ecol Prog Ser 434:1-13

Roscales JL, González-Solís J, Muñoz-Arnanz J, Jiménez B (2011b) Geographic and trophic patterns of OCs in pelagic seabirds from the NE Atlantic and the Mediterranean: a multi-species/multi-locality approach. Chemosphere 85:432-440

> Shaffer SA, Tremblay Y, Awkerman JA, Henry RW and others (2005) Comparison of light- and SST-based geolocation with satellite telemetry in free-ranging albatrosses. Mar Biol 147:833-843

Skira IJ (1986) Food of the short-tailed shearwater, Puffinus tenuirostis in Tasmania. Aust Wildl Res 13:481-488

Smale MJ, Clarke MR, Klages NTW, Roeleveld MAC (1993) Octopod beak identification-resolution at a regional level (Cephalopoda, Octopoda: Southern Africa). S Afr J Mar Sci 13:269-293

Smale MJ, Watson G, Hecht T (1996) Otolith atlas of Southern African marine fishes. Ichthyological Monograph I, JLB Smith Institute of Ichthyology, Grahamstown

Tempera F, Medeiros R, Machete M, Morato T (2009). Carta morfobatimétrica dos Montes Submarinos dos Açores. Departamento de Oceanografia e Pescas

> Thompson DR, Lilliendahl K, Solmundsson J, Furness RW, Waldron S, Phillips RA (1999) Trophic relationships among six species of Iceland seabirds as determined through stable isotope analysis. Condor 101:898-899

Warham J (1955) Observation on the little shearwater at the nest. West Aust Nat 5:31-39

Weimerskirch H, Salamolard M, Sarrazin F, Jouventin P (1993) Foraging strategy of wandering albatrosses through the breeding season: a study using satellite telemetry. Auk 110:325-342

Wilson RP (1984) An improved stomach pump for penguins and other seabirds. J Field Ornithol 55:109-112

Submitted: December 15, 2010; Accepted: February 8, 2012 Proofs received from author(s): April 7, 2012 